\title{
Research on the Relationship between Work Behavior, Personality Traits and Team Performance
}

\author{
Yongdong Chen ${ }^{a}$, Yongxia Bao ${ }^{b}$ \\ Economics and Management School of Beijing Jiaotong University, Beijing 100044, China \\ aydchen@bjtu.edu.cn, b13552512901@163.com
}

\begin{abstract}
Based on the "Big Five Personality" theory, this paper is willing to investigate personal traits, work behaviors, and team performance of five research team members. The analysis process is based on the team-level overall traits and overall performance, and uses statistical analysis methods to analyze the overall traits of the team. The mediation effects of work performance, work behavior, and work behavior were analyzed and relevant conclusions were drawn. The conscientiousness, openness, and pleasantness of team traits have a significant positive effect on job performance. Work behavior plays an intermediary role in team traits and team performance. This conclusion is helpful for personnel selection and incentives in corporate management.
\end{abstract}

Keywords: personality traits; behavior; team performance.

\section{The Question is Raised}

McRaec and Costa define five-factor personality traits as follows: experience openness; responsibility; extraversion; pleasant; neuroticism[1].

Kurt Lewin proposes the behavioral formula $\mathrm{B}=\mathrm{f}(\mathrm{P}, \mathrm{E})$, that is, individual behavior is a function of individual personality traits and their environment.

The basic theory of team performance is the IPO model proposed by McGrath in 1964, which is the source of team performance research [2]. Barrick and Mount use meta-analysis to conclude that the predictive effect of conscientiousness on individual performance is more stable and effective than the other four factors [3].

However, in China, there is less research on the effect of individual traits on organizational performance. Therefore, it is a very meaningful research topic to study the influence of the personal characteristics of the members of an organization on team performance.

\section{Research Hypothesis and Research Methods}

\subsection{Research Hypothesis}

Barry \& Stewart (1998) found through research that conscientiousness, agreeableness, neuroticism, and average ability of members are positively related to team performance [4]. Neuman and Wright (1999) combined individuals with the team and found that "responsible or pleasantly tailored members have a positive influence on team performance [5].The personal characteristics of employees have a certain influence on work behavior.In summary, this study proposes relevant hypotheses between team personality traits and team performance.

H1: Positive correlation between team personality traits and team performance

H2: Positive correlation between improvement of team personality traits and work behavior

H3: Positive correlation between team work behavior and team performance

H4: Job behavior mediates between personality traits and team performance

\subsection{Variable Measurement}

The measurement of the personal characteristics of the team will use the standardized NEO-FFI$\mathrm{R}$ scale. The questionnaire of was compiled by Mccrae and Costa, and the results used in mainland China[6]. The measurement of Work Behavior Scale compiled by Williams \& Anderson. The questionnaire refers to the performance evaluation questionnaires of Liu Wei (2011) and Yang Linbo (2013) [7-8]. 


\subsection{Research Methods}

Barrick et al. proposed three methods for the integration of team characteristics [9].This article discusses the relationship between team traits and performance of the student team and will be discussed using the mean method.This study used SPSS22.0 for correlation analysis and regression analysis to test hypotheses.

\section{Research Results}

\subsection{Correlation Analysis}

According to the correlation analysis, pleasant, conscientious, and open to experience have a significant positive correlation to performance. From table 1, we can infer that the correlation analysis is consistent with the hypotheses H1.

Table 1. Correlation Analysis of Team Traits and Team Performance

\begin{tabular}{c|c|c|c|c|c}
\hline Pearson correlation & Extrapolation & Pleasantness & Responsibility & Neuroticism & Experience Openness \\
\hline Performance & -0.092 & 0.982 & 0.977 & -0.239 & 0.974 \\
\hline
\end{tabular}

From the Pearson correlation coefficient in Table 2, it can be seen that there is a certain correlation between team traits and group work behavior. Among them, work behavior was positively correlated with pleasantness, conscientiousness, and openness of experience[10]. Thus, the second set of hypotheses is verified.

Table 2. Correlation Analysis of Team Traits and Job Behavior

\begin{tabular}{c|c|c|c|c|c}
\hline Pearson correlation & Extrapolation & Pleasantness & Responsibility & Neuroticism & Experience Openness \\
\hline Work Behavior & -0.102 & 0.823 & 0.764 & -0.318 & 0.851 \\
\hline
\end{tabular}

Analysis of the correlation between team behavior and team performance

The correlation coefficient between work behavior and team performance is 0.638 , which also shows that there is a positive correlation between work behavior and team performance. This conclusion confirms that $\mathrm{H} 3$ has a positive effect on the improvement of team performance.

\subsection{Regression Analysis}

This part of the regression analysis is not only to measure the linear relationship between personality traits and team performance, but also to measure the mediating role of work behavior[11].

(1) Regression analysis between personality traits and team performance

Table 3 shows the direct relationship between independent variables (personal traits) and team performance. The Beta value of both experience and experience is greater than zero, indicating a linear relationship between team performance and appetite, conscientiousness, and openness of experience.

Table 3. Regression analysis of personality traits on team performance

\begin{tabular}{c|c|c|c|c|c|c}
\hline \multirow{2}{*}{ Model } & \multicolumn{2}{c|}{$\begin{array}{c}\text { Non-standardized } \\
\text { coefficient }\end{array}$} & \multirow{2}{*}{$\begin{array}{c}\text { Standard } \\
\text { coefficient }\end{array}$} & \multirow{2}{*}{ t } & \multirow{2}{*}{ Significant } \\
\cline { 3 - 7 } \multicolumn{2}{c|}{} & B & Standard error & Beta & & \\
\hline \multirow{4}{*}{1} & (Constant) & -4.647 & .000 & & & \\
\cline { 2 - 7 } & Extrapolation & -.639 & .000 & -.129 & -0.739 & 0.524 \\
\cline { 2 - 7 } & Pleasantness & 2.958 & .000 & .809 & 4.563. & 0.003 \\
\cline { 2 - 7 } & $\begin{array}{c}\text { Experience } \\
\text { Openness }\end{array}$ & .605 & .000 & .109 & 2.319. & 0.002 \\
\cline { 2 - 7 } & Responsibility & .303 & .000 & .089 & 2.108. & 0.002 \\
\hline
\end{tabular}


(2) Regression analysis between personality traits and work behavior

Table 4 shows the direct relationship between personality traits and job performance.The Beta value is greater than 0 , indicating a linear relationship between work behavior and pleasantness, conscientiousness, and openness to experience. Among them, the Beta value of pleasantness is 2.040, which indicates that the predictability of pleasantness on work behavior is much greater than the conscientiousness and openness of experience.

Table 4. Regression analysis of personality traits and work behavior

\begin{tabular}{|c|c|c|c|c|c|c|}
\hline & \multirow[t]{2}{*}{ Model } & \multicolumn{2}{|c|}{$\begin{array}{l}\text { Non-standardized } \\
\text { coefficient }\end{array}$} & \multirow{2}{*}{$\begin{array}{c}\begin{array}{c}\text { Standard } \\
\text { coefficient }\end{array} \\
\text { Standard error } \\
\end{array}$} & \multirow{2}{*}{$\begin{array}{l}\text { Non-standardized } \\
\text { coefficient }\end{array}$} & \multirow[t]{2}{*}{ Significant } \\
\hline & & Standard error & Beta & & & \\
\hline \multirow{5}{*}{1} & (Constant) & -4.225 & .000 & & & . \\
\hline & Pleasantness & 3.067 & .000 & 2.040 & 4.255 & 0.003 \\
\hline & Responsibility & 2.333 & .000 & 1.679 & 3.034 & 0.002 \\
\hline & $\begin{array}{l}\text { Experience } \\
\text { Openness }\end{array}$ & 2.067 & .000 & .745 & 2.786 & 0.002 \\
\hline & Neuroticism & -5.800 & .000 & -2.545 & -4.231 & 0.412 \\
\hline
\end{tabular}

(3) Regression analysis between work behavior and team performance

It can be seen that the standardized regression coefficient of work behavior is 0.986 , and t-test shows that there is a significant positive linear correlation between work behavior and team performance, and team work behavior has a strong predictive effect on work performance.

From this, we can verify that $\mathrm{H} 4$, work behavior has an intermediary effect on personality traits and team performance. At this point, the hypothesis test is completed.

\section{Main Research Conclusions}

In China, there is a lack of research on the overall personality traits of the team and the overall work performance of the team. This paper concludes the following conclusions by researching the relationship between team personality traits, work behaviors, and team performance. Responsibility, and openness of experience are related to team performance. Work behavior plays an intermediary role between the team's overall traits and team performance. That is, team traits will enhance or weaken work behaviors, which will in turn affect team performance. The enthusiasm of the team members is high, the work is full of enthusiasm, the work is responsible, the rules are clear, the members are harmonious, and the students are humble and eager to learn.

\section{References}

[1]. Sheldon, W.H. The varieties of temperament: A Psychology of constitutional differences. New York Harper, Pow, 1942.

[2]. McGrath, J, E. Social Psychology: A Brief Introduction [M]. New York: Holt, Rinehart \& Winson, 1964.

[3]. Barrick M R, Mount M K. The big five personality dimensions and job performance: A metaanalysis. Personnel Psychology, 1991, 44(1): 1 26.

[4]. Barry, B. \& Stewart, G.L. Composition, process, and performance in self-managed groups: the role of personality. Journal of Applied Psychology. 1997, (82), 62.

[5]. Neuman G A, Wright J. Team Effectiveness: Beyond Skills and Cognitive Ability[J]. Journal of Applied Psychology,1999,84, (3).

[6]. Costa, P. T. Jnr., McCrae, R. R. (1985). The NEO personality inventory manual. Odessa, FL: Psychological Assessment Resources. 
[7]. Liu Ye. Study on the Influence of Personal Traits on Managerial Performance[D]. Chengdu Southwest Jiaotong University, 2011.

[8]. Yang Linbo, Shi Guanfeng, Yu Xingde. The relationship among personality traits, distributed leadership and team performance from the perspective of social networks[J]. Management Engineer,2013, 2:1-11.

[9]. Barrick M R, Stewart G L, Neubert M J, et al. Relating member ability and personality to workteam processes and team effectiveness[J]. Journal of Applied Psychology, 1998,83(3): 377 391.

[10]. Neuman G A, Wright J. Team Effectiveness: Beyond Skills and Cognitive Ability[J]. Journal of Applied Psychology,1999,84, (3).

[11]. Yao Ruo-Song, Chen Huai-Jin, Miao Qun-Ying, Research on Big Five Personality Traits and Relationship Performance of Enterprise Employees[J] New Exploration in Psychology, 2013,11(4),374-379. 